\title{
PENGARUH MEDIA CETAK DAN AUDIO VISUAL TERHADAP KEMAMPUAN MENULIS TEKS BERITA PADA SISWA MTS BERGAYA KOGNITIF FIELD DEPENDENT DAN FIELD INDEPENDENT
}

\author{
Khabib Sholeh ${ }^{1}$, Edi Sunjayanto ${ }^{2}$, Bagiya ${ }^{3}$, Frida Nur Aini ${ }^{4}$, Main Sufanti ${ }^{5}$ \\ $1,2,3,4$ Universitas Muhammadiyah Purworejo, ${ }^{5}$ Universitas Muhammadiyah Surakarta \\ e-mail: ${ }^{1}$ khabibsholeh@umpwr.ac.id
}

\begin{abstract}
ABSTRAK
Hasil pembelajaran menulis berita siswa kelas VIII MTs Muhammadiyah Batur, Banjar Negara sangat rendah. Dari 53 siswa yang mencapai ketuntasan belajar hanya 21,88\% (12 siswa) dengan nilai rata-rata 70,83 . Untuk itu, perlu dicarikan solusi berdasarkan kondisi dan teori yang ada dengan mengubah pendekatan pembelajaran dan penggunaan media yang tepat.Penelitian ini bertujuan untuk mendeskripsipengaruh penggunaan mediacetak dan audio visual terhadap kemampuan menulis teks berita siswa kelas VIII. Penelitian ini menggunakan metode kuantitatif dengan jenis eksperimen. Metode pengumpulan data yang digunakan adalah tes dan kuesioner. Hasil penelitian menunjukkan terdapat pengaruh media cetak terhadap kemampuan menulis teks berita dengan $t$ hitung -4.916 dan sig .000dengan taraf signifikan $5 \%$, sehingga $0,000<0,05$ maka data berpengaruh signifikan; terdapat pengaruh penggunaan media audio visual terhadap kemampuan menulis teks berita dengan hasil $\mathrm{t}$ hitung -10,495 dan sig .000 (2-tailed) dengan taraf signifikansi 5\%,terdapat perbedaan pengaruh media cetakan dan audio visual terhadap kemampuan menulis teks beritadengan hasil penghitungan bahwa hasil kemampuan menulis teks berita dilihat berdasarkan nilai postes pada siswa dengan media cetak rata-rata sebesar 74,51 , sedangkan nilai rata-rata siswa dengan media audio visual sebesar 79,92, media audio visual lebih besar pengaruhnya dibandingkan dengan media cetak; dan terdapat perbedaan gaya kognitif yang mempengaruhi kemampuan menulis teks berita pada siswa kelas VIII MTs Muhammadiyah Batur, Banjarnegara. Hal tersebut dapat dilihat berdasarkan total nilai yang diperoleh siswa FD memiliki total rata-rata 78,57 (kelas audio visual), sedangkan rata-rata siswa Fl sebesar 77,90 (kelas media cetak).
\end{abstract}

Kata kunci: media cetak, media audio visual, teks berita

\section{PENDAHULUAN}

Penggunaan media sangat penting untuk memaksimalkan tujuan pembelajaran yang dirancang oleh guru. Media pembelajaran merupakan suatu perantara yang digunakan untuk menyampaikan informasi dengan tujuan dapat memberikan rangsangan kepada siswa untuk belajar. Sebagaimana penjelasan Smaldino, et.al (2011) media diartikan sebagai segala sesuatu yang merujuk pada penyampaian 
informasi dan pesan antara sebuah sumber dan sebuah penerima sebagai wujud dari sarana komunikasi. Terdapat klasifikasi media menurut Degeng (1989), yaitu visual, audio, dan audio visual. Pemakaian media pembelajaran tersebut telah memberikan pengaruh kepada siswa.

Kemasan media pembelajaran yang baik dapat membangkitkan semangat siswa untuk belajar sehingga memperoleh hasil belajar yang maksimal. Selain itu, media juga membawa pengaruh terhadap psikologis (batin, perasaan, sikap, dan karakter) siswa.Media pembelajaran itu banyak ragamnya, dari yang berbentuk audio, media visual, media cetakan, maupun media yang berbasis komputer. Salah satu media yang digunakan dalam proses pembelajaran yaitu media cetak berbasis leaflet (Arsyad,2014:19). Media cetak leaflet dapat digunakan untuk menyampaikan semua jenis materi yang perlu dipelajari oleh peserta didik. Unsur-unsur yang terkandung dalam media cetak leaflet yaitu tulisan (teks) dan gambar (Majid, 2012:177). Salah satu strategi yang dapat digunakan untuk meningkatkan kemampuan mengarang prosa siswa adalah strategi pemodelan berbantuan media cetak.

Dalam strategi ini guru akan memperlihatkan beberapa contoh karangan yang terdapat dalam media cetak, yang mana media cetak yang penulis maksudkan adalah majalah (tabloid), dan buku cerita. Dengan membaca dan menperhatikan carapengarang menyampaikan gagasan dalam tulisannya, siswa akan lebih terispirasiuntuk membuat sebuah karangan. Di samping itu dengan menggunakan media cetak siswa akan terlatih dan terbiasa membaca sehingga dapat menambah perbendaharaan katanya. Seperti yang diungkapkan Dadan (2013:102) bahwa melalui model prosa menulis dan penilaian portofolio dapat meningkatkan ketrampilan menulis siswa sekolah Dasar.

Hasil penelitian yang dilakukan oleh Kausar (2013) mengungkapkan bahwa mahasiswa di International Islamic University Islamabad, sebanyak 91\% memilih menggunakan audio visual untuk mempelajari bahasa. Mahasiswa mengungkapkan melalui media audio visual membantu mengingat kata-kata baru, selain itu mereka juga dapat belajar sesuatu yang sebelumnya belum pernah diketahui. Penelitian lain yang dilakukan oleh Mathew (2013) menyimpulkan bahwa audio visual sebagai media 
pembelajaran mampu merangsang pemikiran dan meningkatkan lingkungan belajar yang kondusif di kelas EFL, mahasiswa jurusan bahasa inggris di Aljouf University, Arab Saudi. Keefektifan penggunaan media audio visual memberikan pelajaran yang bervariasi dan tidak monoton sehingga siswa dapat mengembangkan dan meningkatkan pemahaman pembelajaran secara mandiri.

Hasil penelitian yang dilakukan Ghaedsharafi \& Bagheri (2012) menyimpulkan bahwa media audio visual, audio, dan visual mempunyai pengaruh terhadap kemampuan menulis mahasiswa di Universitas Shiraz Azad Iran. Berdasarkan hasil penelitian eksperimen yang telah dilakukan menunjukkan pemerolehan nilai media audio visual lebih tinggi dibandingkan media audio dan media visual melalui presentasi yang telah dilakukan peneliti. Variabel kondisi pembelajaran erat hubungannya dengan faktor karakteristik siswa. Salah satu karakteristik siswa yang mendominasi perolehan hasil belajar adalah gaya belajar. Gaya belajar merupakan cara siswa dalam belajar melalui strategi tertentu yang diyakini siswa dan sudah menjadikan kebiasaan yang sulit untuk mengubahnya. Salah satu bagian dari gaya belajar adalah gaya kognitif atau gaya berpikir siswa (Keefe, 1987). Informasi tentang gaya kognitif siswa akan bermanfaat untuk proses pembelajaran yang berkaitan dengan strategi, tujuan, evaluasi pembelajaran yang diberikan dan produksi bahan ajar (media dan buku ajar).

Gaya kognitif dapat dibedakan berdasarkan beberapa cara pengelompokkan, salah satunya dilakukan Witkin (1977) yang mengidentifikasi dan mengelompokkan seseorang berdasarkan karakteristik kontinum global analitik. Berdasarkan cara pengelompokkan ini, Witkin membagi gaya kognitif menjadi 2 kelompok yaitu gaya kognitif field dependent (FD)dan field independent(FI). Seseorang dengan gaya kognitif FDadalah orang yang berpikir global, menerima struktur atau informasi yang sudah ada, memiliki orientasi sosial, memilih profesi yang bersifat keterampilan sosial, cenderung mengikuti tujuan dan informasi yang sudah ada, dan cenderung mengutamakan motivasi eksternal, sedangkan orang yang memiliki gaya kognitif $\mathrm{FI}$ adalah seseorang dengan karakteristik mampu menganalisis objek terpisah dari lingkungannya, mampu mengorganisasi objek-objek, memiliki orientasi impersonal, memilih profesi yang bersifat individual, dan mengutamakan motivasi dari dalam diri 
sendiri. Dalam proses pembelajaran, siswa yang memiliki karakteristik gaya kognitifFD akan cenderung fokus pada gambaran umum; hanya mengikuti informasi yang sudah ada; namun dapat bekerja sama dengan baik, karena orientasi sosialnya, sedangkan seseorang dengan karakteristik gaya kognitif $\mathrm{Fl}$ akan cenderung mampu mencari informasi lebih banyak diluar konten yang telah ada; mampu membedakan suatu objek dari objek sekitarnya dengan lebih mudah dan cenderung lebih analitik; dan motivasinya bergantung pada motivasi internal.

Beberapa penelitian yang telah dilakukan terdahulu membuktikan bahwa terdapat pengaruh gaya kognitif terhadap hasil belajar. Hasil penelitian yang dilakukan Darmayanti et al (2013) menyimpulkan terdapat pengaruh interaksi model pembelajaran dengan gaya kognitif terhadap keterampilan proses sains dan pemahaman konsep. Siswa yang memiliki gaya kognitif FI memperoleh skor lebih tinggi dibandingkan siswa FD pada pelaksanaan pembelajaran CTL. Penelitian tersebut membuktikan bahwa gaya kognitif mempunyai pengaruh terhadap keterampilan proses sains dan pemahaman konsep melalui model pembelajaran yang telah diberikan. Hasil penelitian lainnya juga dilakukan oleh Reta (2012) yang menyimpulkan terdapat perbedaan perolehan nilai pada keterampilan berpikir kritis antara siswa field independent (FI) dan siswa field dependent (FD). Siswa yang memiliki gaya kognitif FI memperoleh rata-rata skor lebih tinggi dibandingkan dengan siswa yang memiliki gaya kognitif FD. Hasil penelitian tersebut membuktikan bahwa karakteristik seseorang yang bergaya kognitif FI memiliki kecenderungan berpikir analitik sehingga memudahkan dalam mencapai skor yang maksimal. Hasil Penelitian lainnya yang dilakukan (Agboghoroma, 2015) menunjukkan bahwa gaya kognitif dan penggunaan modul berpengaruh terhadap hasil belajar siswa pada materi ilmu integrasi. Hasil penelitian menunjukkan interaksi siswa pada penggunaan modul dipengaruhi oleh gaya berpikirnya.

Beberapa ahli lain berpendapat bahwa gaya kognitif merupakan jembatan antara kognisi dan tindakan yang memperlihatkan kepribadian seseorang (Stenberg dan Grigorenko, 1997). Basey (2009) mengungkapkan bahwa gaya kognitif merupakan proses atau gaya kontrol yang muncul dalam diri siswa yang secara situasional dapat 
menentukan aktivitas sadar siswa dalam mengorganisasikan, mengatur, menerima, dan menyebarkan informasi dan juga menentukan perilaku siswa tersebut. Dengan demikian, gaya kognitif dapat dikatakan sebagai cara siswa untuk menangkap informasi, mengolah informasi dan mengeksekusi informasi dalam sebuah tindakan atau perilaku ketika proses belajar berlangsung yang dilakukan siswa tersebut secara konsisten.

Penelitian ini menggunakan dua bentuk media yang diterapkan dalam pembelajaran menulis berita di SLTP. Media pembelajaran yang dimaksud adalah media cetak yang berupa koran dan audio visual yang berupa VCD. Pengetahuan tentang kemampuan menulis berita tersebut dapat diketahui melalui perolehan hasil belajar siswa ketika sebelum diberikan pembelajaran dengan media dan sesudah menggunakan media. Penelitian ini berupaya menguji pengaruh yang ditimbulkan oleh penggunaan media cetak dan audio visual dalam pembelajaran serta peran gaya kognitif terhadap kemampuan menulis teks berita pada siswa kelas VIII MTs Muhammadiyah Batur, Kabaupaten Banjarnegara.

\section{METODE PENELITIAN}

Penelitian ini menggunakan pendekatan kuantitatif dengan jenis eksperimen. Penelitian eksperimen dipilih karena penelitian ini berupaya menguji pengaruh yang ditimbulkan variabel bebas yaitu media cetaka dan audio visual terhadap variabel terikat yaitu kemampuan menulis berita, serta peran gaya kognitif sebagai variabel mediasi dalam pengaruh tersebut. Populasi yang digunakan dalam penelitian ini adalah seluruh siswa kelas VIII yang berjumlah108 di MTs Muhammadiyah Batur, Banjarnegara. Sampel yang digunakan adalah semua anggota populasi dengan rincian 39 siswa pada kelas VIIIA dan 39 siswa pada kelas VIIIB. Terdapat dua instrumen utama yang digunakan dalam penelitian ini, yaitu instrumen tes standar Group Embedded Figures Test (Prayekti, 2018); (Moslemi \& Dastgoshadeh, 2010)dan intrumen tes kemampuan menulis berita.

Intrumen GEFT digunakan untuk menentukan gaya kognitif siswa, yaitu gaya kognitif field dependent (FD)dan gaya kognitif field independent(FI). Instrumen ini 
dikembangkan oleh Witkin, terdiri dari 25 item soal. Dalam tes ini siswa harus menemukan gambar sederhana yang tersembunyi dalam gambar yang rumit. Untuk melihat tingkat pencapaian kemampuan menulis berita, digunakan tes yang dikembangkan peneliti yang telah divalidasi ahli serta telah diujicoba sebelum digunakan dalam penelitian. Tes kemampuan menulis berita berupa tes uraian yang disusun berdasarkan jenjang kemampuan taksonomi Bloom revisi Anderson. Instrumen penguasaan konsep dibatasi pada tingkat C1 sampai C4.

\section{HASIL PENELITIAN DAN PEMBAHASAN}

Penulis mengumpulkan data-data yang berkaitan dengan variabel-variabel yang diidentifikasi. Hasl penelitian yang telah dilakukan diketahui melalui hasil uji prasyarat dan uji hipotesis dengan berbantuan komputasi software SPSS 20 for windows.

\section{Uji Prasyarat}

Uji persyaratan yang diperlukan untuk mengetahui sebaran skor dalam penelitian ini digunakan uji normalitas dan homoginitas. Uji tersebut diperlukan sebagai dasar untuk mengetahui data berdistribusi secara normal dan homogen. Pengujian masing-masing dengan menggunakan taraf signifikan $5 \%$. Adapun hasil pengujian dijabarkan pada tabel 1.

Tabel 1. Hasil Uji Normalitas

\begin{tabular}{lcccl}
\cline { 2 - 5 } Kemampuan menulis berita & Nilai K-S-Z & $\mathbf{P}$ & Sig & \multicolumn{1}{c}{ Keterangan } \\
\cline { 2 - 6 } Hasil Pre & 0.797 & 0.153 & .549 & Normal \\
\cline { 2 - 6 } Hasil Post & 0.649 & 0.093 & .794 & Normal \\
\cline { 2 - 5 } & & & &
\end{tabular}

Berdasarkan tabel tersebut dapat dinyatakan bahwa nilai signifikansi lebih besar dari 5\% maka perhitungan pada data dilakukan menggunakan Uji-t karena data berdistribusi dengan normal. Hasil uji homogenitas yang telah dilakukan diketahui dan ditampilkan melalui tabel 2.

Tabel 2. Hasil Uji Homogenitas

\begin{tabular}{llll}
\cline { 2 - 4 } Kemampuan menulis berita $\mathbf{F}$ & \multicolumn{1}{c}{ Sig } & \multicolumn{2}{c}{ Keterangan } \\
\cline { 2 - 5 } Hasil Pre & .399 & .589 & Homogen \\
\cline { 2 - 4 } Hasil post & .294 & .529 & Homogen \\
\cline { 2 - 4 } & & &
\end{tabular}


Perhitungan data dalam penelitian ini juga menggunakan taraf signifikansi 5\%. Tabel di atas menunjukkan bahwa signifikansi lebih besar dari 5\% maka data dapat dikatakan homogen. Berdasarkan hasil uji prasyarat maka dalam penelitian ini menggunakan uji-t (Uji Independent) menggunakan SPSS 20 for windows.

\section{Uji Hipotesis}

Hipotesis dalam penelitian ini digunakan untuk mengetahui pengaruh media cetak terhadap kemampuan menulis teks berita, pengaruh audio visual terhadap kemampuan menulis teks berita, perbedaan pengaruh media cetak dan audio visual terhadap kemampuan menulis teks berita, dan mengetahui perbedaan gaya kognitif yang mempengaruhi kemampuan menulis teks berita.

Tabel 3. Hasil Uji-t Media Cetak

\begin{tabular}{|c|c|c|c|c|c|}
\hline Hasil Belajar & Mean & Stan. De & ev tDf & Sig (2-tail) & Keterangan \\
\hline $\begin{array}{l}\text { Pre } \\
\text { Post }\end{array}$ & -10.296 & 6.368 & -10.495 & 0.000 & Berp \\
\hline
\end{tabular}

Berdasarkan tabel tersebut dapat dikatakan bahwa terdapat pengaruh penggunaan media cetak terhadap kemampuan menulis berita di MTs Batur, Banjarnegara. Hasil tersebut dapat diketahui melalui hasil uji t sebesar -10,495 dan sig .000 dengan menggunakan perbandingan t tabel $5 \%$, sehingga $0,000<0,05$ maka data berpengaruh signifikan. Hipotesis kedua digunakan untuk mengetahui pengaruh penggunaan media audio visual terhadap kemampuan menulis teks berita. Hasil perhitungan yang telah dilakukan dapat diketahui melalui tabel 4.

Tabel 4. Hasil Uji-t Media Audio Visual

\begin{tabular}{lcccccc} 
& Hasil Belajar & Mean & Stan. Dev & tDf & \multicolumn{2}{c}{ Sig (2-tail) Keterangan } \\
Pre & -13.075 & 5.853 & 13.088 & 51 & 0.000 & Berpengaruh \\
Post & & & & & & \\
\cline { 2 - 5 }
\end{tabular}

Berdasarkan tabel tersebut dapat diketahui bahwa terdapat pengaruh yang signifikan penggunaan media audio visual terhadap kemampuan menulis teks berita pada siswa kelas VIII di MTs Muhammadiyah, Batur, Banjar Negara. Hasil tersebut diperoleh dengan cara membandingkan nilai probabilitas dengan taraf signifikansi $5 \%$. Pengaruh media cetak dan audio visual ditampilkan pada tabel 5. 
Tabel 5. Hasil Uji-t Media Cetak dan Audio Visual

\begin{tabular}{|c|c|c|c|c|c|c|c|c|}
\hline \multirow[t]{2}{*}{ Variable } & \multicolumn{3}{|c|}{ Hasil Belajar Mean } & \multirow{2}{*}{$\begin{array}{r}\text { Selisih } \\
15.64\end{array}$} & \multirow{2}{*}{$\begin{array}{l}\mathbf{t} \\
5.879\end{array}$} & \multirow{2}{*}{$\begin{array}{l}\text { Df } \\
76\end{array}$} & \multicolumn{2}{|c|}{ Sig (2-tail) Keterangan } \\
\hline & Cetak & Pre & 57.87 & & & & 0.000 & \\
\hline & & Post & 75.51 & & & & & Ada perbedaar \\
\hline \multirow[t]{2}{*}{ Audio visu } & & Pre & 67.38 & 13.54 & & & & \\
\hline & & Post & 78.92 & & & & & \\
\hline
\end{tabular}

Tabel 5 menunjukkan hasil penghitungan bahwa hasil kemampuan menulis teks berita dilihat berdasarkan nilai postes pada siswa dengan media cetak rata-rata sebesar 74,51, sedangkan nilai rata-rata siswa dengan media audio visual sebesar 79,92. Berdasarkan hasil tersebut maka dapat disimpulkan terdapat perbedaan kemampuan menulis berita siswa melalui penggunaan media cetak dan audio visual. Media audio visual lebih besar pengaruhnya dibandingkan dengan media cetak terhadap kemampuan menulis berita.

Pengujian hipotesis keempat dilakukan untuk mengetahui perbedaan gaya kongitif siswa yang memengaruhi kemampuan menulis berita melalui penggunaan media cetak dan audio visual. Hasil penghitungan yang telah dilakukan diketahui dan ditampilkan melalui tabel 6.

Tabel 6. Perbedaan Gaya Kognitif

\begin{tabular}{|c|c|c|c|c|c|c|}
\hline Kelas & \multicolumn{2}{|c|}{ Hasil Belajar } & Gaya Kognitif & Mean & $\mathbf{N}$ & Keterangan \\
\hline \multirow{4}{*}{ Cetak } & \multirow{2}{*}{\multicolumn{2}{|c|}{ Pre }} & FD & 56.41 & 27 & \multirow{12}{*}{ Ada perbedaan } \\
\hline & & & FI & 60.77 & 26 & \\
\hline & \multirow{2}{*}{\multicolumn{2}{|c|}{ Post }} & FD & 74.64 & & \\
\hline & & & FI & 74.35 & & \\
\hline \multirow{4}{*}{ Audio I } & \multirow{2}{*}{\multicolumn{2}{|c|}{ Pre }} & FD & 65.90 & 27 & \\
\hline & & & FI & 66.89 & 26 & \\
\hline & \multirow{2}{*}{\multicolumn{2}{|c|}{ Post }} & FD & 80.30 & & \\
\hline & & & FI & 79.92 & & \\
\hline \multirow{4}{*}{ Total } & \multirow{2}{*}{\multicolumn{2}{|c|}{ Pre (Cetak) }} & FD & 61.54 & & \\
\hline & & & FI & 63.61 & & \\
\hline & \multirow{2}{*}{\multicolumn{2}{|c|}{ post (Audio Visual) }} & FD & 78.57 & & \\
\hline & & & FI & 76.90 & & \\
\hline
\end{tabular}

Berdasarkan tabel tersebut didapatkan hasil bahwa terdapat dua gaya pada siswa kelas VIII MTs Muhammadiyah Batur, Banjarnegara dengan rincian 27 siswa FD dan 26 siswa FI. Hasil analisis tersebut dapat dideskripsikan bahwa terdapat perbedaan hasil belajar pada siswa yang memiliki gaya berpikir FD pada media cetak dan FD pada 
audio visual, demikian juga pada siswa yang bergaya kognitif $\mathrm{Fl}$ pada kelas dengan media cetak juga memiliki perbedaan dengan audio visual.

Jika dilihat perbedaannya pada saat prates siswa FI lebih unggul. Masingmasing siswa yang bergaya kognitif FI lebih unggul dibandingkan siswa FD dengan rincian perolehan rata-rata (mean) 67,89 pada kelas audio visual dan 61,77 pada kelas media cetak, sedangkan pada saat postes 80,53 pada audio visual dan 73,64 pada kelas cetak. Namun, pada saat postes memiliki hasil yang berbeda, dimana siswa FD menjadi lebih unggul dari kelas FI. Hal tersebut dapat dilihat berdasarkan total nilai yang diperoleh dimana pada siswa FD memiliki total rata-rata 78,57 pada siswa FD (kelas audio visual), sedangkan rata-rata siswa FI sebesar 76,90 (kelas cetak).

\section{Pengaruh Media Cetak terhadap Kemampuan Menulis Berita}

Penggunaan media cetak dalam pembelajaran memberikan pengaruh terhadap hasil belajar siswa di bidang Bahasa Indonesia yaitu pada materi menulis berita. Hasil analisis data penelitian sebagaimana diuraikan sebelumnya menunjukkan bahwa terdapat pengaruh media cetak terhadap kemampuan menulis berita dengan hasil $\mathrm{t}$ hitung -10,495 dan sig .000 (2-tailed) dengan membandingkan taraf signifikansi 5\%. Media cetak merupakan media yang dapat digunakan untuk pengumpulan, pengolahan dan penyimpanan serta penyampaian informasi. Cetakan dengan kemampuan membaca yang dimiliki telah memberikan rangsangan sehingga siswa termotivasi untuk belajar.

Hal tersebut sebagaimana pendapat Mozen dan Morrow (Dhieni, 2008: 5.21) yang menyatakan bahwa terdapat tiga rangkaian perilaku membaca yang berkembang secara terpisah yaitu perhatian terhadap fungsi, bentuk dan konvensi cetakan. Proses membaca dini dilakukan melalui pengenalan simbol-simbol atau lambang huruf. Lambang huruf tersebut dipelajari satu persatu, yang kemudian dirangkaikan menjadi kata-kata. Menurut Hamdani (2011:262) media cetak merupakan media surat kabar, majalah, danterutama buku. Pemanfaatannya tentu saja menuntut kemampuan dan minat baca serta kemampuan berbahasa yang tinggi". Proses membaca juga sangat dipengaruhi oleh dukungan dan interaksi dari lingkungan. Pengalaman langsung merupakan cara belajar anak dalam menyerap suatu pengetahuan. 
Berdasarkan hasil postes yang memberikan peningkatan dari hasil prates yang dapat dilihat dari selisihnya sebesar 15.64. Hal tersebut menunjukkan bahwa bahwa kontribusi penggunaan media cetak dalam pembelajaran untuk menjelaskan kemampuan menulis berita siswa adalah $42,13 \%$ dan selebihnya dipengaruhi faktorfaktor lain, seperti kemampuan berbahasa, kecerdasan intelegensi, minat baca atau bisa juga dari faktor luar, yaitu dorongan dan motivasi.

\section{Pengaruh Media Audio Visual terhadap Kemampuan Menulis Berita}

Penggunaan media audio visual dalam pembelajaran memberikan pengaruh terhadap hasil belajar siswa di bidang bahasa Indonesia dengan hasil t hitung 13.008 dan sig (2-tailed) .000 dengan membandingkan taraf signifikansi 5\%. Media audio visual dalam bentuk video kegiatan dapat memengaruhi kemampuan menulis siswa serta menjadi solusi ketika siswa merasa jenuh diberikan pembelajaran menulis secara tradisional (konvensional) oleh guru kelas.

Pembelajaran menggunakan media audio visual telah mengoptimalkan peran guru sebagai motivator, hal tersebut terbukti dengan perhatian dan motivasi siswa untuk mengikuti proses menyimak pada saat penelitian. Siswa secara aktif terlibat dalam kegiatan belajar seperti mengamati, mencari tahu, memberikan saran, mendengar dan bertukar pendapat dengan siswa lainnya melalui penggunaan media audio visual. Hal tersebut sebagaimana pendapat Sudjana (2003) yang menjelaskan bahwa melalui video seseorang dapat belajar mandiri dan aktif dalam kegiatan yang berlangsung.

Media audio visual sebagai salah satu media yang menginterpretasikan hubungan erat antara dengar dan pandang mampu menggugah perasaan dan pemikiran bagi siswa. Audio visual berhasil mengefektifkan proses pembelajaran serta komunikasi dan interaksi antara guru dan siswa dalam proses pembelajaran di sekolah sehingga tujuan pembelajaran hasil pembelajaran tercapai secara maksimal. Berdasarkan hasil refleksi pada akhir pembelajaran siswa menyampaikan bahwa video yang ditayangkan membuat mereka terbawa dengan setiap kejadian yang terjadi, siswa juga merasa telah berada di setiap tempat yang terjadi di dalamnya. 
Sebagaimana pendapat (Smaldino, 2011) yang menjelaskan video dapat membawa peserta didik ke tempat yang belum pernah dan mungkin tidak bisa mereka kunjungi.

Media audio visual merupakan media yang tepat digunakan pada materi menulis berita. Efektivitas pembelajaran menulis berita melalui penggunaan media audio visual dapat diketahui dari hasil perbedaan prates dan postes yang telah dilakukan. Selisih yang didapatkan melalui kedua tes tersebut sebesar 13,54. Hal tersebut menujukkan bahwa media audio visual berkontribusi 35,78 \% dalam hal kemampuan menulis berita pada pembelajaran bahasa Indonesia, selebihnya kemampuan tersebut dipengaruhi oleh beberapa faktor lain, seperti yang sudah dijelaskan sebelumnya pada pembahasan pengaruh media audio terhadap kemampuan menulis berita.

\section{Perbedaan Gaya Kognitif terhadap Kemampuan Menulis Berita}

Gaya kognitif merupakan kebiasaan siswa untuk memproses dan mengolah informasi yang diterimanya menjadi sesuatu yang terus diingat agar menjadi ingatan jangka panjang. Sebagaiaman Dalam kegiatan memecahkan suatu kasus, terdapat beberapa faktor yang mempengaruhi sudut pandang siswa dalam menyikapi suatu masalah. Salah satunya berupa gaya kognitif siswa. Gaya kognitif seseorang menekankan pada proses menerima, menyimpan, serta mengolah informasi yang ia dapatkan dari sekitar (SUCIA, 2017). Jika suatu individu dominan dengan gaya kognitif yang dimiliki, maka secara langsung maupun tidak langsung akan mempengaruhi perilau dan aktivitas siswa.

Perbedaan gaya berpikir yang dimiliki setiap individu menjadikan gaya kognitif terbagi menjadi dua jika dilihat dari sudut pandang pengolahan informasi yaitu gaya kognitif FI dan FD. Hasil penelitian menunjukkan bahwa setiap kelas memiliki dua gaya berpikir yang dimiliki siswa. Kelas audio lebih banyak siswa dengan gaya kognitif FI dibandingkan FD dengan rincian 17 siswa FD dan 22 siswa FI. Berbeda halnya dengan kelas audio visual yang lebih banyak siswa bergaya kognitif FD dibandingkan dengan FI, meskipun hanya selisih 1 angka saja dengan rincian 20 siswa FD dan 19 siswa FI.

Berdasarkan hasil analisis siswa dengan gaya kognitif FI memang lebih unggul dalam perolehan nilai pada saat postes. Hal tersebut dikarenakan siswa dengan gaya FI 
yang lebih berkarakter tidak bergantung lapangan, siswa bisa dengan mudah menyerap sesuatu baik informasi dan pesan dengan sendirinya tanpa bantuan. Hal tersebut sesuai dengan pendapat Witkin, et al (1977) yang menyatakan bahwa siswa dengan gaya berpikir bebas dapat lebih mudah menerima informasi dengan mandiri. Berbeda halnya dengan siswa dengan gaya berpikir lebih bergantung di lapangan membutuhkan bantuan orang lain untuk memproses informasi yang diterimanya. Hasil penelitian pada saat postes siswa FD lebih unggul dibandingkan FI pada kelas audio visual, bahkan ketika diakumulasikan untuk kedua kelas siswa dengan gaya kognitif FD lebih unggul dalam memperoleh nilai dibandingkan dengan siswa FI. Mengetahui hal tersebut membuktikan bahwa treatment yang diberikan berpengaruh pada siswa.

Hasil penelitian menunjukkan bahwa siswa FD lebih membutuhkan seseorang untuk membantu menyelesaikan masalahnya, selama diberi perlakuan siswa dibimbing dan diarahkan untuk menjawab pertanyaan dan menangkap isi bacaan mengalami peningkatan nilai pada saat postes. Siswa FI yang lebih beranggapan bahwa dirinya bisa tanpa bantuan orang lain dan memilih untuk memecahkan masalah secara mandiri memperoleh hasil yang lebih rendah walaupun selisihnya sedikit sekali. Perbedaan gaya kognitif FI atau FD masing-masing siswa dapat diketahui melalui sebuah tes yang disebut Group Embedded Figures Test(GEFT) (Prayekti, 2018),(Moslemi \& Dastgoshadeh, 2010). Dengan Dengan demikian kemampuan literasi matematika dapat ditinjau dari gaya kognitif siswa masing-masing.Siswa FI mempunyai motivasi di dalam dirinya yang mendorong individu tersebut untuk dapat menyelesaikan masalah tanpa bergantung orang lain. Umumnya individu FI mempunyai banyak cara atau strategi yang digunakan dalam belajar hal tersebut dimungkinkan terjadi karena siswa FI banyak mencoba hal baru yang diperolehnya dengan kesadaran sendiri. Siswa yang memiliki gaya kognitif field dependence berkebalikan dengan siswa FI, siswa dengan gaya kognitif FD berpikir secara global dan bergantung di lapangan. Ketika dihadapkan masalah individu FD cenderung belajar dengan orang lain sehingga dapat menghargai pendapat orang lain. Siswa FD lebih menyukai belajar secara berkelompok dan kegiatan berdiskusi. 
Hal demikian membuktikan bahwa siswa FD lebih menyukai pelajaran yang berhubungan dengan sosial misalnya bahasa Indonesia, sedangkan siswa FI lebih suka pada ilmu pasti atau ilmu pengetahuan seperti perhitungan angka, pemecahan masalah, teori, dan karya ilmiah. Sesuai dengan pendapat Witkin, et. al (1977) yang menyatakan bahwa siswa FD lebih tertarik pada ilmu-ilmu sosial dan lebih membutuhkan bantuan seseorang dalam menyelesaikan pekerjaannya.

Berdasarkan hasil penelitian yang menunjukkan bahwa perbedaan gaya kognitif memengaruhi kemampuan menulis berita melalui penggunaan media cetak dan audio visual, maka maka guru perlu menyesuaikan pembelajaran dengan gaya tersebut. Sebagaimana hasil penelitian tersebut, guru perlu memerhatikan gaya kognitif siswa agar tujuan pembelajaran tercapai maksimal. Paparan sebelumnya telah menjelaskan bahwa siswa FI dimungkinkan lebih mempunyai gaya belajar dengan cara visualisasi. Guru dapat menghadirkan gambar-gambar, bagan, rumus, geometri, dan media media lain yang dapat mendukung pembelajaran di kelas. Siswa dengan gaya kognitif FD yang lebih menyukai cara belajar secara berkelompok dan juga sosial dimungkinkan mempunyai gaya belajar auditori. Guru dapat memberikan pembelajaran menggunakan media audio dan memberikan persoalan yang mengarahkan adanya diskusi kelas.

\section{KESIMPULAN}

Berdasarkan rumusan masalah, paparan data, hasil penelitian, dan pembahasan, maka hasil penelitian ini dapat disimpulkan sebagai berikut. Pertama, hasil penelitian menunjukkan bahwa terdapat pengaruh penggunaan media cetak dalam pembelajaran terhadap kemampuan menulis berita pada siswa kelas VIII di MTs Batur, Banjarnegara. Hal tersebut didapatkan melalui hasil perhitungan pretest dan postest pada kelas dengan media cetak. Perbedaan perolehan skor yang didapat pada saat pretest berbeda pada saat postest dengan rincian perolehan rata-rata $($ mean $)=57,87$ dengan standart deviasi 6,105 pada saat pretest, sedangkan pada saat postest dengan rincian perolehan rata-rata $($ mean $)=75,51$ dengan standart deviasi sebesar 4,454. Kedua, hasil penelitian menunjukkan bahwa terdapat pengaruh 
penggunaan media audio visual terhadap kemampuan menulis teks berita pada siswa kelas VIII di MTS Batur, Banjarnegara. Hal tersebut didapatkan melalui perbedaan hasil nilai pretest dan postest yang telah dilakukan. Adapun rincian yang menunjukkan adanya pengaruh dapat dilihat melalui perolehan rata-rata (mean) pada saat pretest 67,38 dengan standart deviasi 5,225, sedangkan pada saat posttest rata-rata (mean) meningkat menjadi 78,92 dengan standart deviasi sebesar 4,233.

Ketiga, hasil penelitian menunjukkan terdapat perbedaan pengaruh penggunaan media cetak dengan media audio visual, kelas dengan perlakuan audio visual lebih unggul hasil nilainya. Hal tersebut dapat diketahui melalui hasil uji-t (Independent Sample Test) yang membuktikan nilai t hitung>t tabel dengan taraf signifikansi $5 \%$ yaitu 0,000 . Hal yang perlu diketahui bahwa rentangan hasil nilai yang diperoleh pada kelas dengan media cetak lebih besar jika dibandingkan dengan kelas audio visual dengan rincian 15,64 pada kelas media cetak dan 13,54 pada kelas audio visual. Hal tersebut menunjukkan bahwa efektifitas media cetak lebih unggul jika dibandingkan audio visual dalam pembelajaran menulis berita. Keempat, berdasarkan hasil analisis penelitian yang telah dilakukan terdapat perbedaan gaya kognitif pada siswa kelas VIII MTS Batur. Perbedaan tersebut yang memengaruhi kemampuan menulis siswa melalui penggunaan media cetak dan audio visual. Hal tersebut dapat dilihat melalui perolehan skor rata-rata (mean) pada saat pretestkelas media cetak yaitu 56,41 siswa FD dan 60,77 siswa FI. Sedangan hasil postes menunjukkan 74,35 siswa FD dan 74,64 siswa FI. Kelas audio visual memperoleh nilai rata-rata (mean) pada saat prates sebesar 65,90 siswa FD dan 66,89 siswa FI. Sedangkan hasil postes sebesar 80,30 siswa FD dan 79,92 siswa FI. Dengan demikian, maka siswa FD memperoleh ratarata (mean) yang lebih tinggi dari siswa Fl.

Berdasarkan penelitian yang telah dilakukan, ada beberapa saran yang diberikan peneliti kepada peneliti lanjutan dan guru. Pertama, guru diharapkan mampu melanjutkan penggunaan media cetak dan media audio visual dan mampu memvariasikan keduanya dalam proses pembelajaran. Selain hal tersebut guru juga perlu memerhatikan gaya kognitif yang dimiliki siswa dan menyesuaikan dengan metode mengajar serta media yang digunakan sehingga proses pembelajaran dapat 
berjalan dengan baik. Kedua, disarankan bagi peneliti lain agar meneliti lebih lanjut tentang pengaruh media dan gaya kognitif terhadap variabel yang berbeda dengan latar dan permasalahan yang berbeda.

\section{DAFTAR PUSTAKA}

Agboghoroma, T. E. (2015). Interaction Effects of Cognitive Style and Instructional Mode On Students' Knowledge of Integrated Science. European Journal of Research and Reflection in Educational Sciences, 3(1), 47-54. Retrieved from http://www.idpublications.org/wp-content/uploads/2015/01/Interactioneffects-of-cognitive-style-and-instructional-mode-on-students\%E2\%80\%99knowledge-of-integrated-science.pdf.

Arsyad, Azhar. 2014. Media Pembelajaran. Jakarta: Raja Grafindo Persada

Bassey, Sam. W \& Umoren, Grace. 2009. Cognitive Styles, Secondary School Students'Attitude And Academic Performance In Chemistry In Akwalbom State Nigeria. $\quad$ www.hbcse.tifr.res.in/episteme/episteme-2/eproceedings/bassey. diakses 22 Agustus 2011.

SUCIA, V. (2017). Pengaruh Gaya Komunikasi Guru Terhadap Motivasi Belajar Siswa. Komuniti: JurnalKomunikasi Dan Teknologi Informasi, 8(5), 112. https://doi.org/10.23917/komuniti.v8i5. 2942

Dadan,D. 2013. Strategi Pembelajaran Menulis dengan Model Prosa Menulis dan Penilaian portofolio di Kelas V SDN Sindangraja Kabupaten Sumedang. Jurnal Pendidikan. Universitas Pendidikan Indonesia.

Darmayanti, N.W.S., Sadia, W., \& Sudiatmika, A. A. I. A. R. (2013). Pengaruh Model Collaborative Teamwork Learning terhadap Keterampilan Proses Sains dan Pemahaman Konsep Ditinjau dari Gaya Kognitif. 3(1). Retrieved from http://pasca.undiksha.ac.id/ejournal/index.php/jurnal_ipa/article/view/553/345.

Degeng, I. N. S. (1989). Ilmu Pengajaran Taksonomi Variabel. Jakarta: Depdikbud.

Dhieni, Nurbiana. dkk. 2008. Metode Pengembangan Bahasa. Jakarta: Universitas Terbuka.

Ghaedsharafi, M., \& Bagheri, M. S. (2012). Effects of Audiovisual, Audio, and Visual Presentations on EFL Learners' Writing Skill. International Journal of English Linguistics, 2(2), 113-121. DOI: http://dx.doi.org/10.5539/ijel.v2n2p113.

Hamdani. 2011. Strategi belajar mengajar. Bandung: CV. Pustaka setia

Kausar, G. (2013). Students' Perspective of the Use of Audio Visual Aids in Pakistan. Journal of Education, 68(3), DOI: 10.7763/IPEDR. 2013. V68. 3.

Keefe, James W. dan J.S. Monk.1987. Learning Style: Theory and Practice. Reston,Va: National Assosiation of Scundery School Principal. 
Mathew, N. G., \& Alidmat, A. O. H. (2013). A Study on the Usefulness of Audio-Visual Aids in EFL Classroom: Implications for Effective Instruction. International Journal of Higher Education, 2(2), 86-92. DOI: https://doi.org/10.5430/ijhe.v2n2p86.

Abdul Majid. 2012. Belajar dan Pembelajaran Pendidikan Agama Islam Belajar dan Pembelajaran Pendidikan Agama Islam. Bandung: PT. Remaja Rosdakarya.

Moslemi, N., \& Dastgoshadeh, A. (2010). The Relationship Between Cognitive Styles and Young Adult Learners'Preferences for Written Corrective Feedback La relación entre los estilos cognitivos y las preferencias deretroalimentación correctiva escrita delos estudiantes*. 24(2), 120-5927. https://doi.org/10.19183/how.24.2.338

Prayekti. (2018). The Influence of Cognitive Learning Style and Learning Independence on the Students' Learning Outcomes. Higher Education Studies, 8(2), 37. https://doi.org/10.5539/hes.v8n2p37

Reta, I. K. (2012). Pengaruh Model Pembelajaran Berbasis Masalah terhadap Keterampilan Berpikir Kritis Ditinjau dari Gaya Kognitif Siswa. Jurnal Pendidikan IPA Indonesia, 2(1), 1-17 Retrieved from http://pasca.undiksha.ac.id/ejournal/index.php/jurnal ipa/article/view/403/195.

Sucia, V. (2017). Pengaruh Gaya Komunikasi Guru Terhadap Motivasi Belajar Siswa. Komuniti: Jurnal Komunikasi dan Teknologi Informasi, 8(5), 112. https://doi.org/10.23917/komuniti.v8i5. 2942

Smaldino,et.al. (2011). Instructional Technology and Media for Learning. Colombus: Upper Saddle River.

Sternberg, R.J. \& Grigorenko, E.L. (1997). Are Cognitive Style Still in Style?. American Psychologist, 52 (7), hlm 700-712

Sudjana \& Rivai. (2003). Audiovisual. Jakarta: Bina Aksara.

Witkin, A. H. et al. (1977). "Field-Dependent and Independent Cognitive Style and Thei Educational Implication". Review of Educational Research, 47 (1), hlm 1-64. 